Nepal Agric. Res. J. Vol. 9, 2009

\title{
An Empirical Analysis of Resource Productivity of Wheat in Eastern Tarai Region of Nepal
}

\author{
Ram B. Bhujel, Ram N. Jha and Bindeshwar Yadav \\ Regional Agriculture Research Station, Tarahara, Sunsari, Nepal
}

\begin{abstract}
Different types of resource conservation technology (RCT) in wheat cultivation have been recently introduced and use of seed cum fertilizer zero till drill machine is one of them which was used in eastern terai region in wheat season of 2006/2007. A survey was carried out to study the productivity of wheat and compare the production between traditional and RCT method of cultivation. Altogether 31 farmers were interviewed with semi-structured questionnaires. Model used to estimate the productivity for both the methods was significant $(\mathrm{p}<0.01)$ which explained 96 and 97 per cent variation due to independent variables under study in wheat production of traditional and RCT method, respectively. Farmers used $160 \mathrm{~kg}$ seed/ha in traditional method while in RCT method it was $122 \mathrm{~kg} / \mathrm{ha}$. Similarly, they applied 148 and $137 \mathrm{~kg}$ nutrients as a total of nitrogen, phosphorus and potash in traditional and RCT method, respectively. Average production of wheat grain in traditional and RCT method was 2456 and $2714 \mathrm{~kg} / \mathrm{ha}$ giving average gross margin of Rs 16750.00 and Rs $23301.00 /$ ha, respectively. This revealed 10 per cent reduction in total costs and 29 per cent increase in return by RCT method.
\end{abstract}

Key words: Gross margin, productivity, resource conservation technology

\section{INTRODUCTION}

Wheat is the third major cereal crop of the country after rice and maize. The area, production and productivity of wheat in 1968/1969 was $208000 \mathrm{ha}, 233000 \mathrm{mt}$ and $1119 \mathrm{~kg} / \mathrm{ha}$ which in 2005/2006 has increased to 672040 ha, $1394126 \mathrm{mt}$ and $2074 \mathrm{~kg} / \mathrm{ha}$, respectively (Chand et al 1990, ABPSD 2000, ABPSD 2006). Similarly, during 2006/2007, $1515139 \mathrm{mt}$ of wheat; was produced in the country from 702664 ha of land with an average yield of $2156 \mathrm{~kg} / \mathrm{ha}$ (ABPSD 2007). It indicates that the improved wheat technologies have contributed to increase more than 300 per cent in area, about 600 per cent in production and 185 per cent in yield. Use of resource conservation technology to minimize costs and increase production has become essential for economic production of wheat.

Wheat contributed to more than 23 per cent to total edible food requirement of the country during 2004/2005 (ABPSD 2006). Export and import of wheat shows that the wheat worth of Rs $4,88,000,000.00$ was imported from India while equivalent to Rs 19,95,207.00 was exported to overseas countries during 2005/2006. 
Resources are generally either economic or natural which are vital to determine wheat production. Technology that enhances the saving of economic and natural resources without declining production level is Resource Conservation Technology (RCT). Furthermore, either efficient use of resources to attain at least previous level of production, or to increase that level with similar dose of inputs but with applying different technology is RCT. Increasing rate of inputs like seed, labor, fertilizers, fuel and also their unavailability in time has challenged to generate technologies that require less resources to attain more production. RCT thus refers to efficient use of inputs like seed, fertilizer, irrigation, labors and money without declining yield level rather to enhance its increment. Farmers for wheat cultivation generally plough the field 2-3 times after paddy harvest and left it to dry/to bring the soil-moisture into optimum level or sometimes the plowing of field is hindered due to over moisture in the field and ultimately the wheat sowing is delayed. RCT, thus refers to the economic use of inputs for optimum production of the crops.

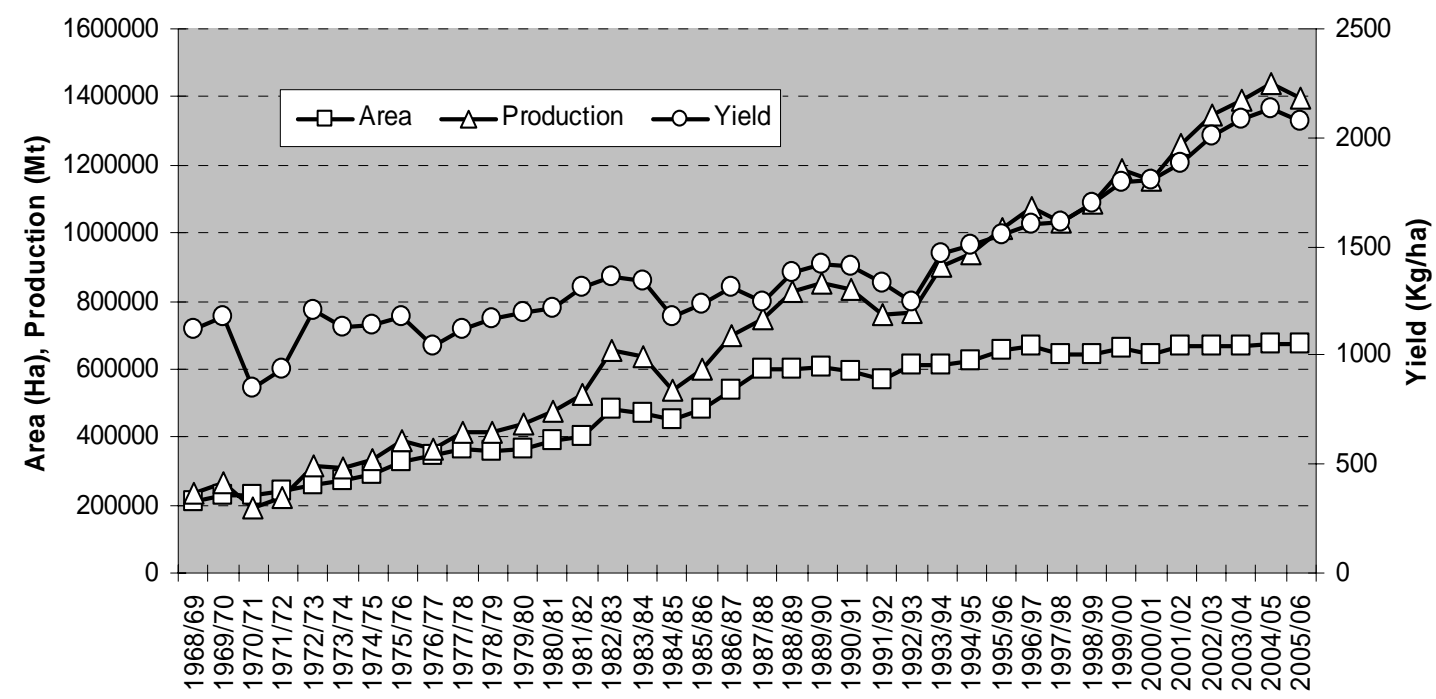

Figure 1. Trend of area, production and productivity of wheat in Nepal.

Regional Agriculture Research Station, Tarahara, Sunsari has been carrying out on-station research on wheat crop to find out high yielding varieties suitable for Eastern Terai Region (ETR). Since variety is one of the governing factors in wheat, the resource conservation technology (RCT) without decreasing the yield has also been inevitable for its sustainability. Farmers are well aware of conserving the resources right from the very beginning and they had used different methods of RCT in Nepal. Wheat cultivation using no-till technique was first started at the bank of Ridi Khola in Palpa district. Even before the initiation of wheat research, no-till wheat cultivation was practiced by the farmers of Bhaktapur district and the research on no-till wheat cultivation was initiated at Janakpur and Bhairahawa during mid seventies to minimize yield loss because of late planting (Giri 2001). Different tillage options such as zero tillage, surface seeding, bed planting and reduced tillage with Chinese seed drill as RCT have been found very effective to increase the production and productivity of rice-wheat system at significantly profitable level. These technologies greatly help in reducing the cost of cultivation by eliminating land preparation cost (Rs 2000.00 to Rs $2500.00 / \mathrm{ha}$ ) and fostering timely establishment of wheat crop (Pathic et al 2003). Seed cum Fertilizer Zero Till Drill Machine in ETR was used to follow RCT in wheat cultivation during 2063/2064. This machine is also one of the technologies of resource conservation such as seed, fertilizer, labor and water. In this year, perhaps the first time in ETR, the seed cum fertilizer zero till drill machine was introduced in farmers' field for wheat sowing of Saptari, Sunsari and Morang districts. 
The main objective of the study was to compare the production cost between traditional method of wheat sowing and by using seed cum fertilizer zero till drill machine. The specific objectives were:

1. to study the resource productivity of wheat,

2. to compare production of wheat between traditional method and RCT method of sowing,

3. to compare production cost and gross margin, and

4. to assess the production constraints.

\section{MATERIALS AND METHODS}

During the year 2063/2064 (2006/2007), a survey was carried out to assess the production of wheat cultivated by using seed cum fertilizer zero till drill machine and traditional method of the farmers. Farmers of Saptari, Siraha and Morang districts who used the machine to sow wheat were selected to take primary information. Altogether 31 sample farmers were selected purposefully. The same farmers had applied RCT and in some area they had grown wheat by their own traditional practices. Thus, all the selected farmers had applied both of the methodologies for wheat cultivation. A semistructured questionnaire was developed for interview schedule. Face to face interview was scheduled with the respondent farmers. Information on traditional method of wheat sowing and RCT method was the main focus including the costs and production.

Secondary information was collected from publications, group discussions and key informants. Review was made through different reports published in journal and proceedings. The data was fed into computer and analyzed statistically using MS excel and SPSS package. Empirical analysis was focused on comparing the outputs between traditional and RCT method of wheat cultivation by the farmers. Since the variable cost is important in the short run which influence the decision making of the farmers to be considered for deriving the profits in both of the methods.

\section{Analytical framework}

In order to find out the productivity of the resources, production function approach was used for which the Cobb-Douglas production function was employed. In this production function the input coefficients constituted the respective elasticities which is the single most advantage of this production function and is mostly applied in agricultural research. The Cobb-Douglas production function was modified to include dummy variables for number of irrigation as Equation 1.

$\mathrm{Y}=\mathrm{AX}_{1}{ }^{\mathrm{b} 1} \mathrm{X}_{2}{ }^{\mathrm{b} 2} \mathrm{X}_{3}^{\mathrm{b} 3} \mathrm{X}_{4}{ }^{\mathrm{b} 4} \mathrm{X}_{5}^{\mathrm{b} 5} \mathrm{X}_{6}{ }^{\mathrm{b} 6} \mathrm{X}_{7}^{\mathrm{b} 7} \mathrm{X}_{8}{ }^{\mathrm{b} 8} \mathrm{X}_{9}{ }^{\mathrm{b} 9} \mathrm{X}_{10}{ }^{\mathrm{b} 10} \mathrm{D}_{1}{ }^{\mathrm{b} 11} \mu$

Where,

$\mathrm{Y}=$ Gross returns from wheat cultivation (Rs.)

$\mathrm{A}=$ Intercept

$\mathrm{X}_{1}=$ Area of wheat $(\mathrm{Ha})$

$\mathrm{X}_{2}=$ Value of seed (Rs.)

$\mathrm{X}_{3}=$ Cost on chemical fertilizers (Rs.)

$\mathrm{X}_{4}=$ Cost on agrochemicals (Rs.)

$\mathrm{X}_{5}=$ irrigation charge (Rs.)

$\mathrm{X}_{6}=$ Cost on bullock labor (Rs.)

$\mathrm{X}_{7}=$ Tractor charges (Rs.)

$\mathrm{X}_{8}=$ Labors' cost (Rs.)

$\mathrm{X}_{9}=$ Harvesting charge (Rs.)

$\mathrm{X}_{10}=$ Threshing charge (Rs.)

$\mathrm{D}_{1}=$ Dummy for number of irrigation (1 for up to 3 irrigations, and 0 for otherwise)

$\mathrm{b}_{1}$ to $\mathrm{b}_{11}=$ Elasticities coefficients 
$\mu=$ Random error

Above model was estimated using Ordinary Least Square (OLS) approach after converting it into $\log$ linear form and thus, the estimation form of equation (1) was transferred into equation (2) as:

$\ln Y=\ln A+b_{1} \ln X_{1}+b_{2} \ln X_{2}+b_{3} \ln X_{3}+b_{4} \ln X_{4}+b_{5} \ln X_{5}+b_{6} \ln X_{6}+b_{7} \ln X_{7}+b_{8} \ln X_{8}+b_{9} \ln X_{9}+b_{10} \ln X_{10}+$

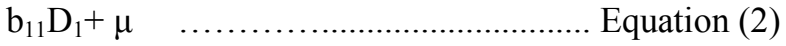

The coefficient values imply their contribution to the production of wheat grown using traditional or RCT method by the farmers.

The total variable cost was estimated by using equation (3):

$\mathrm{Y}=\sum \mathrm{x}_{\mathrm{i}}$ ..Equation (3)

Where,

$\mathrm{Y}=$ Total cost (Rs.)

$\mathrm{x}=$ Costs (Rs) incurred in $\mathrm{i}^{\text {th }}$ inputs.

Gross return was calculated by:

$\mathrm{Y}=\sum \mathrm{x}_{\mathrm{i}} \times \mathrm{P}_{\mathrm{i}}$ Equation (4)

Where $\mathrm{Y}=$ Gross return (Rs.). It is the total value of total grain, husk and straw production.

$\mathrm{X}=$ Quantity of $\mathrm{i}^{\text {th }}$ products. It is quantity of grain, husk and straw production.

$\mathrm{P}=$ Price of $\mathrm{i}^{\text {th }}$ products $(\mathrm{Rs} / \mathrm{kg})$

Similarly, the net return was estimated by using

$\mathrm{Y}=\sum \mathrm{y}_{\mathrm{i}}-\sum \mathrm{x}_{\mathrm{i}}$ Equation (5)

Where,

$\mathrm{y}_{\mathrm{i}}=$ Value of the $\mathrm{i}^{\text {th }}$ products.

$\mathrm{x}_{\mathrm{i}}=$ Total cost of inputs incurred in the cultivation.

\section{RESULTS AND DISCUSSION}

Among 31 sample farmers, 93 per cent were male while 7 per cent were female and the age of the respondent farmers was found to be 44 in average.

\section{Land holdings and source of irrigation}

Farmers were having both the irrigated and unirrigated land out of which farmers were found to be holding 4.28 ha of irrigated land in average. Farmers possessing more than 1 to 1.5 ha and more than 3 ha were equally contributed to total holdings as 29.03 per cent of each category followed by 16.14 per cent of holding more than 1.5 to 2 ha (Table 1). Similarly, the average holding of unirrigated land among the sample farmers was 0.11 ha which indicates the majority of wheat growers had irrigated land, because 84 per cent farmers had irrigated land and only 16 per cent of them operated unirrigated land too. Thus average operational holding was 4.59 ha. Majority of the farmers had more than 1 to 2 ha of total operated land including irrigated and unirrigated environment (Table 2). It was 38.71 per cent followed by more than 5 ha which constitutes 22.58 per cent among the sample farmers. The source of irrigation was mostly the irrigation canal which constituted 81 per cent. Remaining farmers had deep and shallow tube well. 
Table 1. Average irrigated and unirrigated land holding of sample farmers, 2007

\begin{tabular}{lcccccr}
\hline SN & $\begin{array}{c}\text { Operational } \\
\text { irrigated } \\
\text { land area, ha }\end{array}$ & $\begin{array}{c}\text { No. of } \\
\text { farmers }\end{array}$ & $\begin{array}{c}\text { Per } \\
\text { cent }\end{array}$ & $\begin{array}{c}\text { Operational } \\
\text { unirrigated } \\
\text { land area, ha }\end{array}$ & $\begin{array}{c}\text { No. of } \\
\text { farmers }\end{array}$ & $\begin{array}{c}\text { Per } \\
\text { cent }\end{array}$ \\
\hline 1 & Up to 0.5 & 2 & 6.45 & 0 & 26 & 83.88 \\
2 & $>0.5-1$ & 2 & 6.45 & Up to 0.5 & 3 & 9.68 \\
3 & $>1-1.5$ & 9 & 29.03 & $>0.5-1.5$ & 1 & 3.22 \\
4 & $>1.5-2$ & 5 & 16.14 & $>1.5-2$ & 1 & 3.22 \\
5 & $>2-2.5$ & 1 & 3.22 & & & \\
6 & $>2.5-3$ & 3 & 9.68 & & & \\
7 & $>3$ & 9 & 29.03 & & & \\
\hline
\end{tabular}

Source: Field survey, 2007.

Table 2. Operational land holding of sample farmers, 2007

\begin{tabular}{lccr}
\hline SN & Operational land area, ha & No. of farmers & Per cent \\
\hline 1 & Up to 1 & 4 & 12.90 \\
2 & $>1-2$ & 12 & 38.71 \\
3 & $>2-3$ & 4 & 12.90 \\
4 & $>3-4$ & 2 & 6.45 \\
5 & $>4-5$ & 2 & 6.45 \\
6 & $>5$ & 7 & 22.58 \\
\hline
\end{tabular}

Source: Field survey, 2007.

\section{Cropping intensity}

Average cropping intensity of the sample farmers was 177 per cent where more than 45 per cent had up to 180 to 200 per cent followed by 38.71 per cent of farmers that had more than 180 to 210 per cent (Table 3). Similarly, more than 210 per cent cropping intensity was also found among 16 per cent of the sample farmers.

Table 3. Cropping intensity

\begin{tabular}{llcr}
\hline SN & Cropping intensity, \% & No. of farmers & Per cent \\
\hline 1 & Up to 150 & 7 & 22.58 \\
2 & $150-180$ & 7 & 22.58 \\
3 & $>180-210$ & 12 & 38.71 \\
4 & $>210$ & 5 & 16.13 \\
\hline
\end{tabular}

Source: Field survey, 2007.

\section{Seed rate}

Farmers in traditional method were found using high seed rate. The average seed rate was found to be $159.68 \mathrm{~kg} / \mathrm{ha}$ and about 68 per cent farmers used more than 120 to $150 \mathrm{~kg}$ seed/ha (Table 4). In case of RCT method average seed used was $122.37 \mathrm{~kg} / \mathrm{ha}$ and more than 87 per cent farmers used $120 \mathrm{~kg}$ seed/ha. 
Table 4. Average seed rate used by the farmers in wheat cultivation

\begin{tabular}{llcrrrrr}
\hline \multirow{2}{*}{ SN } & \multicolumn{3}{c}{ Traditional method } & & \multicolumn{3}{c}{ RCT method } \\
\cline { 2 - 3 } \cline { 6 - 7 } & Seed, kg/ha & No. of farmers & Per cent & & Seed, kg/ha & No of farmers & Per cent \\
\hline 1 & Up to 120 & 1 & 3.23 & & 120 & 27 & 87.10 \\
2 & $>120-150$ & 21 & 67.74 & & $>120-130$ & 2 & 6.45 \\
3 & $>150-180$ & 7 & 22.58 & & $>140-150$ & 2 & 6.45 \\
4 & $>180-210$ & 2 & 6.45 & & & \\
\hline
\end{tabular}

Source: Field survey, 2007.

\section{Use of nutrients}

The main source of nitrogen was Urea and DAP while that of phosphorus and potash was DAP and Muriate of potash. Average use of $\mathrm{N}: \mathrm{P}_{2} \mathrm{O}_{5}: \mathrm{K}_{2} \mathrm{O}$ in traditional method was $72.52: 43.23: 20.93 \mathrm{~kg} / \mathrm{ha}$ while in RCT method it was 77.70:48.46:21.71 kg/ha showing no significant difference in nutrient application. Thus total nutrient used in RCT and traditional method was 147.86 and $136.69 \mathrm{~kg} / \mathrm{ha}$ respectively. More than 32 per cent farmers applied $>100$ to $125 \mathrm{~kg}$ of nutrients per ha both in traditional as well as in RCT method. Farmers were equal in applying more than 150 to $175 \mathrm{~kg} / \mathrm{ha}$ in RCT method (Table 5).

Table 5. Average nutrients (nitrogen + phosphorus + potash) used by the farmers in wheat cultivation

\begin{tabular}{llcrccc}
\hline \multirow{2}{*}{ SN } & \multicolumn{3}{c}{ Traditional method } & & RCT method & \\
\cline { 2 - 6 } & Nutrient, kg/ha No. of farmers & $\begin{array}{c}\text { Per } \\
\text { cent }\end{array}$ & $\begin{array}{l}\text { Nutrient, } \\
\text { kg/ha }\end{array}$ & No of farmers & $\begin{array}{c}\text { Per } \\
\text { cent }\end{array}$ \\
\hline 1 & Up to 100 & 4 & 12.90 & $>100-125$ & 10 & 32.26 \\
2 & $>100-125$ & 10 & 32.26 & $>125-150$ & 6 & 19.35 \\
3 & $>125-150$ & 6 & 19.35 & $>150-175$ & 10 & 32.26 \\
4 & $>150-175$ & 5 & 16.13 & $>175-200$ & 5 & 16.13 \\
5 & $>175-200$ & 5 & 16.13 & & & \\
6 & $>200$ & 1 & 3.23 & & & \\
\hline
\end{tabular}

Source: Field survey, 2007.

\section{Variable costs and production of wheat}

Total variable costs incurred in traditional and RCT method was Rs 21716.25 and 19546.45/ha giving a net return of Rs 16750.06 and 23301.26/ha, respectively. Production of wheat was found different in both of the methods. The average yield in traditional and RCT method was 2455.81 and $2714.35 \mathrm{~kg} / \mathrm{ha}$ respectively. The share of fertilizers was highest in both of the methods which was 24 and 29 per cent in traditional and RCT method respectively (Figure 2). The total benefit cost ratio was 1.77 in traditional method and 2.19 in machine used RCT method. 

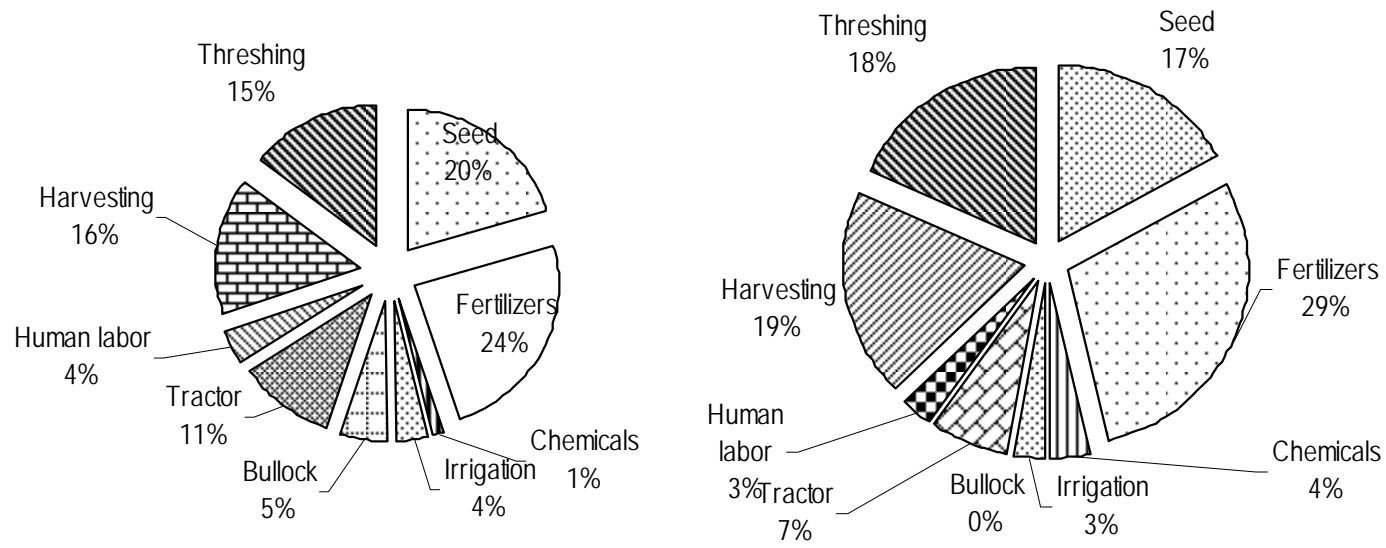

\section{Figure 2. Share of variable costs in traditional and RCT method (left to right) of wheat} cultivation.

The resource productivity of inputs used in traditional method indicated the area, chemical, number and cost of irrigation, harvesting and threshing as statistically significant (Table 6). Area has an elasticity of 1.05 which defines that 1 per cent increase in area would result in 1.05 per cent increase in production. Similarly, the cost on chemical, irrigation, harvesting and threshing is also significant. The negative value of irrigation shows that the farmers are paying high for irrigation charge while the dummy for number of irrigation has positive elasticity of 0.33 which indicates one per cent increase in number of irrigation would result 0.33 per cent increase in production. Despite significance in harvesting and threshing they have negligible value and reveals to maintain the cost in harvesting and threshing which are unbalanced. The model applied was significant $(p<0.01)$ with adjusted $\mathrm{R}^{2}$ value of 0.96 . It implies that the model is successful to explain 96 per cent variation in wheat production under traditional method due to independent variables taken under study.

\section{Table 6. Resource productivity in wheat cultivation under traditional method}

\begin{tabular}{llrrr}
\hline SN & Explanatory variables & Elasticities & Standard errors & T statistics \\
\hline 1 & Intercept & $10.11^{* * *}$ & 0.71 & 14.23 \\
2 & Area & $1.05^{* * *}$ & 0.11 & 9.59 \\
3 & Seed & 0.07 & 0.06 & 1.20 \\
4 & NPK & -0.007 & 0.01 & -0.50 \\
5 & Chemical & $0.01^{*}$ & 0.01 & 1.72 \\
6 & Irrigation & $-0.13^{* *}$ & 0.05 & -2.50 \\
7 & Bullock labor & -0.0008 & 0.0009 & -0.86 \\
8 & Tractor & -0.003 & 0.01 & -0.32 \\
9 & Human labor & 0.04 & 0.07 & 0.51 \\
10 & Harvesting & $0.02^{* *}$ & 0.01 & 2.29 \\
11 & Threshing & $-0.02^{* *}$ & 0.008 & -2.23 \\
12 & Dummy for no of & $0.33^{* * *}$ & 0.12 & 2.75 \\
\hline irrigation & Adjusted $\mathrm{R}^{2}$ & & & \\
& F value $(11,19)$ & $0.96^{* * *}$ & & \\
& Observations & 67.29 & & \\
\hline
\end{tabular}

NPK, Total of nitrogen $+\mathrm{P}_{2} \mathrm{O}_{5}+\mathrm{K}_{2} \mathrm{O} .{ }^{* * *},{ }^{* *},{ }^{*}$, Denotes significant $(p<0.01,0.05$, $0.10)$. 
The model applied to explain variation in wheat production due to explanatory variables included under RCT method was significant $(\mathrm{p}<0.01)$. It proves that the model has explained 97 per cent variation in wheat production due to independent variables under study which has been derived from adjusted $\mathrm{R}^{2}$ value of 0.97 in the model. Cost on seed and human labor is statistically significant (Table 7). It means one per cent increase in seed and human labor would increase 0.53 and 0.05 per cent increase in production, respectively. However, the seed rate has limit to certain extent which can not be determined here. Similarly, the cost on human labor can still be considered. Other variables are non-significant that imply the similar use by the farmers and not varied significantly. Though most of the independent variables (area, NPK, chemical, irrigation, tractor, harvesting, threshing and no. of irrigation) are non-significant and have negative value (area, chemicals, tractor, harvesting, threshing and no. of irrigation), which in general indicates that a marginal increase in these inputs would not raise significantly the total value of output realized. However, the inputs applied by farmers in RCT method of wheat cultivation did not vary significantly which also reveals that they are well aware of using inputs efficiently if the technology is acceptable and economical.

Table 7. Resource productivity in wheat cultivation under RCT method

\begin{tabular}{|c|c|c|c|c|}
\hline $\mathrm{SN}$ & Explanatory variables & Elasticities & $\begin{array}{r}\text { Standard } \\
\text { errors } \\
\end{array}$ & $\mathrm{T}$ statistics \\
\hline 1 & Intercept & 2.79 & 3.61 & 0.77 \\
\hline 2 & Area & -0.09 & 0.42 & -0.2 \\
\hline 3 & Seed & $0.53 *$ & 0.31 & 1.68 \\
\hline 4 & NPK & 0.44 & 0.29 & 1.53 \\
\hline 5 & Chemical & -0.003 & 0.01 & -0.23 \\
\hline 6 & Irrigation & 0.02 & 0.08 & 0.27 \\
\hline 7 & Bullock labor (Not used) & - & - & - \\
\hline 8 & Tractor & -0.01 & 0.01 & -0.90 \\
\hline 9 & Human labor & $0.05^{* * *}$ & 0.02 & 2.70 \\
\hline 10 & Harvesting & -0.002 & 0.018 & -0.13 \\
\hline 11 & Threshing & -0.05 & 0.10 & -0.55 \\
\hline \multirow[t]{4}{*}{12} & $\begin{array}{l}\text { Dummy for no. of } \\
\text { irrigation }\end{array}$ & -0.17 & 0.13 & -1.27 \\
\hline & Adjusted $\mathrm{R}^{2}$ & $0.97 * * *$ & & \\
\hline & F value $(10,20)$ & 118.50 & & \\
\hline & Observations & 31 & & \\
\hline
\end{tabular}

\section{Production constraints}

Wheat is generally grown by the farmers who are assured to supply irrigation. Farmers in discussion expressed the problems of getting quality input materials like seed and fertilizers. Timely availability of seed and fertilizers is also lacking. The demand of wheat seed is high but the supply through both the public and private sector is still not sufficient. Generally farmers did not mentioned about the loss from insects/pests and diseases, however, in RCT method they experienced more weeds which were controlled by applying herbicides. Increased price of seeds, fertilizers, fuel and lubricants, agrochemicals, labors has made the farmers to think twice whether to grow wheat or not, but they are to grow at least for their own consumption and thus can hardly escape from its cultivation. Furthermore, excess moisture in rice field has delayed wheat sowing in traditional 
method. Farmers having tractor can buy seed cum fertilizer zero till drill machine and all categories of farmers can not buy it.

In RCT method, farmers experienced the lack of availability of machine, high price of the machine, skilled operator of the machine and local mechanics for regular maintenance of the machine. They mentioned that the field should be well leveled which may not be in all conditions, specially the weed free (Stubbles) field after paddy harvest where the bottom part of the straw may be left at the field. In RCT method, weeds can not be controlled without herbicides application which may threat the environmental pollution.

\section{CONCLUSION}

Wheat cultivation is being expensive due to increase in labor and input price which can be solved to some extent by using resource conservation technology. Cultivation of wheat by using seed cum fertilizer zero till drill machine is one of the methods of RCT. The result has shown that by the use of this machine the costs on input variables can be reduced by 10 per cent while the return can be increased by 29 per cent which is encouraging information for wheat farmers. The benefit cost ratio was 1.77 and 2.19 respectively in traditional and RCT method of wheat cultivation. Production function showed the scope of increasing wheat yield in traditional method too. But it requires more investment and farmers can not get rid of labor problems and efficient use of seed, fertilizers and irrigation. In other hand they can not sow wheat in time if moisture is high in the field and become late to prepare the field and to bring the field into optimum moisture condition for which they have to wait. But in RCT method soil structure is not disturbed, seed and fertilizers are efficiently used, amount and time of irrigation water is less than the tilled field, timely sown and production is comparatively high. There is no need of using human labor and it is completely free from using bullocks in the current situation where raising bullocks is difficult due to lack of family labor and unavailability of feeds.

The result of the study has clearly supported the use of RCT method which is beneficial to farmers in many aspects and can cope with their existing problems of particularly the labor and inputs' use. However, every farmer can not buy the machine and those who are financially capable to buy the machine need to be encouraged by giving appropriate support services and facilities. Development of market for hiring machines in local market will help not only to owner of the machine but can provide services to all other farmers who can hire the machine and save the cost. It will have demonstration effect which is expected to be multiplied within a short span of years. Participatory research and scaling up programs need to be developed and also the training programs for local mechanics and farmers for its maintenance and availability of different machinery accessories which can be maintained by the dealers/hardware suppliers automatically on demand. Furthermore, RCT method would have chance to encourage farmers to grow wheat commercially and requires the policy support at the national level.

\section{ACKNOWLEDGEMENTS}

Authors are thankful to the respondent farmers who provided valuable information to find out the real output of traditional and RCT method of wheat cultivation. All those who directly/indirectly supported to this study are highly acknowledged. 


\section{REFERENCES}

ABPSD. 2000. Statistical information on Nepalese agriculture 1999/2000. Agri-Business Promotion and Statistics Division, Ministry of Agriculture and Cooperatives, Government of Nepal, Singh Darbar, Kathmandu. P. 114.

ABPSD. 2006. Statistical information on Nepalese agriculture 2005/2006 (2062/63). AgriBusiness Promotion and Statistics Division, Ministry of Agriculture and Cooperatives, Government of Nepal, Singh Darbar, Kathmandu.

ABPSD. 2007. Statistical information on Nepalese agriculture 2006/2007 (2063/2064). Agri-Business Promotion and Statistics Division, Ministry of Agriculture and Cooperatives, Government of Nepal, Singh Darbar, Kathmandu. P. 4.

Chand SP, BD Gurung and PG Rood. 1990. Farmers' traditional wisdom, where does it stands within the present agricultural research system of Nepal. PAC occasional paper no. 4. Pakhribas Agriculture Centre, Dhankuta, Nepal.

Giri G. 2001. History of no-till (surface/relay) wheat planting in Nepal. In: Advances in agricultural research in Nepal (HK Manadhar, CL Shrestha, RK Shrestha and SM Pradhan, eds). Proceedings of the first SAS/N Convention, 29-31 Marg 1999, Kathmandu. SAS/Nepal. Pp. 68-76.

Pathic DS, DP Sherchan and RK Shrestha. 2003. Recent spread and impact of improved crops technologies in Nepal. In: Proceedings of the $6^{\text {th }}$ National Outreach Workshop held at NARC (M Joshi and N Thakur, eds), 4 July 2002, Kathmandu, Nepal. Outreach Research Division, NARC, Kathmandu, Nepal. Pp. 62-75. 